UDC 930

\title{
HISTORICAL RECORDS ON MEDICAL CULTURE OF NORTHERN BLACK SEA REGION PEOPLE
}

\author{
I. Chernysheva, L. Belova \\ Volgograd state medical university. Volgograd, Russian Federation \\ iravale@yandex.ru belovalubov@gmail.com
}

\begin{abstract}
The authors cover peculiarities of people medical culture, inhabiting the territories of the Northern Black sea region. These territories represent a certain scientific interest, as through many centuries migration processes took place there. Medical culture enrichment of separate people occurred in consequence of numerous tribes interaction, having various healing traditions. Curative, phylactic, hygienic customs of people, lived in the distinguished region, their religious ideas, and behavior samples, aimed to preservation, maintenance and promotion of health, available disease prevention techniques for the medicine of that time are appeared to be the medical culture constituent part. The medical culture analysis is provided on the ground of written, archaeological, anthropological sources and paleopathology data. The works of antique authors, containing facts about methods and ways of treatment, information about healers, about hygiene level, about region climate conditions influence to people health status are considered to be the written sources, analyzed by authors. Archaeological and anthropological sources contain the valued material about health status, undergone traumas and diseases. With the help of them one can trace the life mode influence to emersion and development of these or those diseases and peculiarities of their treatment. Medical treatment tradition is considered in the context of medical culture and it is interpreted by authors as social, political, cultural and economic power, the part of cultural genesis general process and one of the person sociocultural adjustment mechanisms. People medical culture is represented as an essential component of the world culture.

Key words: historical sources, medical culture, healing, anthropology, the Scythians, the Sarmatians
\end{abstract}

The Northern Black sea region and contiguous steppe territories - one of the unique regions, where the processes of migration, interaction of numerous tribes, having their healing traditions, took place for centuries. At the same time formation of curative, phylactic, hygienic people skills aimed to preservation, maintenance and fortification of health, diseases prevention techniques, and also continuity of medical and scientific knowledge took place [4, p.54]. In connection with this, historical sources represent significant scientific interest: written, anthropological, ethnographical, reflecting healing development peculiarities of various people, inhabiting the given territories in old time. Study of sources on ancient people medical history is hampered by limitation and complexity of work with them. It is worth mentioning that working with the sources one should resort to social, cultural consequences of medicine development that can contribute to formation of "integral person" conception, as a factor of historical process.

The significant part of information about this territory and its population was obtained from Greek authors. Greek misty ideas about Black sea coast are reflected in stories of ancient Greece and legends. With emersion of Greek colonists constant settlements in VI c. B.C.E. entering into mutual relations with local tribes, the interest in Greece to the Northern Black sea region significantly grew and the number of data about it, penetrating to Greek literature, increased. Herodotus devoted the significant part of the historical work to description of the given region. There he mentioned about Cimmerian tribes, which he called "milkers of fillies". Medical treatment skills of the Cimmerians were connected with treatment of various traumas using medicinal herbs and products of nomadic cattle breeding $[3,205]$ At the turn of VII - VI c. B.C.E. Cimmerians were superseded by Scythian tribes. 
One has more extensive information about healing at Scythian tribes, left by ancient tribes. Thus Hippocrates gave the following characteristics to the appearance and body tympanum of Scythian people: "Scythian people differ with thick, fleshy, unfledged, and non muscular body; the belly has exceeding abundance of moisture... Thank to corpulency and absence of hair on body they look similar, men resemble women and women resemble men". Moreover the Scythians are solid and "do not know fatigue". Besides, "the women differ with amazingly unfledged and feeble body composition". Hippocrates explains the mentioned weaknesses through the live (and through the upbringing for men) in tilt carts, sedentary pastime accordingly. "Corpulency" of women, according to Hippocrates, is appeared to be the main reason of children limited number of the Scythians. As Hippocrates mentions, slaves-concubines give birth faster than wedded wives [1, 35].

Hippocrates gave higher priority to the diet, as soulful and corporal harmony mainly depended from regular nutrition. The Scythian diet was rather balanced: The Scythians ate boiled beef and horsy cheese, drank mare's milk and melt-water. From besot drinks the Scythians usually preferred hop beer. But, participating in campaigns to the Front Asia, they got acquainted with wine, and to $\mathrm{V}$ century B.C.E. the beer was substituted with Greek wines imported in great scopes. The Scythians often drank to excess, for what Greek people did not fail to accuse them in drunkenness. Hippocrates in his writing "About air, water and localities" and also diseases, occurring among the Scythians, notices intense pains in joints, wounds on the thighs and limp, which were the consequence of riding, besides "the most honorable" men are amenable to this disease, whereas "the poor men suffer from this disease less, as they do not ride". Also the father of medicine paid his attention to eunuchoidism, spread among the rich Scythians. According to Hippocrates "these so called sacrificers and prophets", exhausted their bodies and led themselves to exaltation, to have possibility to emit prophetic conjurations. Some historians of medicine refer them to professional healers.

At the same time mentions about Scythian healers-diviners enaries - effeminate men are met in the other sources. Herodotus called them "Saturnian" in relations with women. He asserted that mainly diviners concerned with disease diagnostics among the Scythians. Androgyny of Scythian fortunetelleras is described, as "female disease", sent as punishment for plunder of Aphrodite Urania sanctuary [8, 132-133]. Hippocrates considered that problems with potency and femineity are connected with body friability and appeared to be the consequence of ridding. According to Hippocrates, sexual debility mainly occurred from the custom of venesection behind the ears. Also according to Hippocrates, venesection was an ordinary case for Scythians "... both veins behind the ears are phlebotomized, and when the blood run out, then owing to weakness they fall asleep" [15, p.13]. One more method of the Scythians treatment, described by Hippocrates in writing "About the air, water, localities" is connected with living climate peculiarities of people: "the evidence is moisture abundance in their bodies: the majority of the Scythians, and mainly all the nomads have firing of shoulders, arms, hands, chest, thighs and legs; they do it exceptionally in consequence of the natural moisture abundance in the body and its softness, as otherwise by reason of moisture body and weakness they cannot neither strain bows, nor give impulse during darts; but during firing moisture surplus dries out in members, and as a consequence the body makes stronger..." [7]

Archaeological sources testify about surgical practice grounds of nomadic Scythians. Surgery - scythian sets jaw to the traumatized soldier, extracts tooth, bandages leg to the injured man is portrayed on the famous Kul-Obskaya vase, which is stored in Hermitage, and dated to V-IV c. B.C.E. [15, 14-15]. Surgical instruments and their images were detected by archeologists in Chertomlytskii Kurgan (in middle reaches of Dnieper). The information about the Scythians hygiene is obtained from the descriptions of the Greeks. Herodotus tells about paired baths in detail, as one of the most significant hygienic 
custom of the Scythians. The baths represented the separate "cabin", inside of which there was a water tank and red-hot stones, and intense vapor going from them. The Scythians clean themselves with a pair of baths after funerals. The Scythian women made and use the first analogy of soap: grinded pieces of cypress, cedar, incense on the stone, adding water, they cover the bodies with this liquid batter $[6,156]$. The Scythians wore long hair, and cut them short or shaved with an iron razor only in ritual goals. After the close communication with the Greeks, the Scythians began to cut or shave moustache and grew beards. The Scythians accumulated a great experience in phytogenic medications using. Thus, historians A.Martsellin, Herodotus, Plinii and Feofrast wrote about rhubarb, or the Scythian herb, used for wound healing and "against asthma diseases". Plinii testified that "the Scythian herb" rhubarb from Meotian swamps exported from Scythia to Greece, Italy and other countries. Alexandrian doctors Kteziya and Aristogiton also admired the medicinal properties of the Scythian herb.

Herodotus marked the special bitter taste of herbs in Pontic heaths, which increases bilis quantity more than any other herb. Veterinarian Pelagonii (IV c. B.C.E.) wrote that Greek and Roman doctors widely used "Pontic absintii" (wormwood) calamus and hare roots. The Scythians also knew the peculiarities of many banewort herbs, including aconite, which is called the "king of poison", in virtue of strong poisonous properties. But the Scythian healers also knew the other aconite properties - possibility to cope with the strongest diseases. Analyzed the properties of many other herbs, the Scythians began to grow them in the gardens and backyards. Information about "curative plantations" is met at Plinii, Plutarkh, Ovidii Nazon, Martsellin, Feofrast.

In VII-VI c. B.C.E. the Scythian doctors Anakharsid and Toksarid became famous in Greece. It is considered that Anakharsid (or Anarkhasis) taught his people to propitiate angry divinities and keep to diets in fiery diseases. Anakharsid visited Greece at the time of Solon and distinguished himself by "deep wisdom and abstinence". Plutarkh in his writing "The feast of seven wisemen" described one scene, where Anakharsid, talking with the daughter of wiseman Kleobul, "told her in detail, what people eat in Scythia and what purifications they did during diseases". $[12,148]$ Toksarid who was together with Anakharsid in Athens was let into Asklepiad (i.e. doctors). He lived in Greece at a premium, concerned with medical practice with great success and even after death came to earth, to liquidate plague epidemic. For this the Athenians created the monument to Toksarid and annually sacrifice a white horse.

Savromatsky tribes lived to the east from the Scythians behind the river Don. In V-VI centuries B.C.E. they formed the great union of tribes, who occupied steppe territories of Ural and Volga region. Affinity between the Scythians and the Sarmatians was noticed by Strabon, who confirmed even that the Sarmatians were one of the Scythian tribes. And in truth, the Scythian and Sarmatian culture is closely and inseparably connected with each other. The Sarmatian social system also was close to social system of the Scythians. In the collective sense of the word the nomadic and settled tribes of the North Caucasus, Don-Azov territory and the Volga region steppe part were called the Sarmatians. Fragmentary information about medical culture and medical treatment of the Sarmatians and Savromatians tribes was found at ancient authors. According to the testimony of the ancient writers, the Sarmatian women ride, shoot from the bows, dart, and do not get married, till they shoot three enemies. The authors mention about the "female custom of burning the right breast to obtain the whole power and juice wealth to the right shoulder and hand". The legend of Amazons has the real roots and reflects certain features of social system, in the form of matriarchy long and preserved in some ancient tribes.

Writers report details about everyday life of the Sarmatian Amazons. Thus, meat and dairy foods prevailed in the Sarmatian women ration. They preferred to eat tortoises, snakes, lizards, scorpions, but they did not eat bread. The clothes of the Sarmatian wom- 
en, consisting from bloomers, shirt and coat was not only comfortable, but also beautiful. Ovidy mentions about some elements of male clothes - trousers and winter vestment from skins. Information of ancient writes about custom to paint bodies is preserved. Thus, Claudius Elian (II - begining III C. A.D.) reports: "I notice that some people from foreign tribes use the famous herbs to paint their bodies for the sake of beauty and constant custom. At least, women of barbarous tribes cover their faces with various vegetative ointments, but the men from the Daks and Sarmatians tribes also paint their bodies" [9]. The Sarmatians wore long hair and did not cut bears, and if a tattoo covered the face, then it was not also distinctively seen. In II c. Sextus Empiricus noticed that some Egyptians and Sarmatians did a tattoo on newborn children [10,78].

Head deformation was one more Sarmatian custom, mentioned in the sources. This custom is specific for archeologic culture of the late Sarmatians. The skulls in this region had a ring deformation, which drained the head [10,99]. The similar deformation can be obtained, if one coils a special bandage on the head. The given custom, evidently, was defined by aesthetical tastes of population, and, accordingly, those who had a longer head, were the most beautiful. Considering that the ruler, personifying his people in front of the highest powers in the archaic societies, had to be strong and beautiful, such person was elected as a leader. It is also possible that the head deformation testified about a person nobly born. There is no unite opinion concerning the deformation influence on human physiology. Some researchers suppose that it induced hallucinations, and this could influence on psyche in whole $[10,103]$, however the others considered that ring deformation did not lead to serious defection [10, 104]. The original appearance of the Sarmatians induced complex reaction of Romans. Thus, bearded faces with long hair, and also aggressive and severe look of the Sarmatians made a repellent impression on Roman poet Publii Ovidii Nason. But his compatriot - Roman historian Ammian Martsellin, vice versa, admired the beauty of the Sarmatians, describing them as "high and beautiful, with rather blond hair".

The data of the domestic anthropology and paleopathology give the most interesting material about the diseases of the Sarmatians. Thus, D.G. Rokhlin, after examination of skeletal remains of the Sarmatians buryings in Volga region, gave the description of gumboil traces, jaws atrophy, deformed arthrosis of joints, vertebrae diseases, syphilitic changes on bones, terebration and the whole row of wounds [13, p. 193-205]. M.A. Finkelstein made paleopathology roentgen examination of the 18 Sarmatian skeletons of various periods and found traces of rick on the 5 skeletons, and also noted the syphilitic changes in the form gummatous plaques on the male skull of 45 years [14, p. 205-207]. M.A. Sokolova examined 125 skulls (III c. B.C.E. - VI c. A.D.) from the burial grounds of low Volga region, detected six cases of frontal internal hyperostosis. The researcher connected emersion of the given pathologic defection with the complex influence of adverse factors, such as unbalanced nutrition, constant ridding [5, 208]. Anthropologists under the leadership of A.P. Buzhilova researched 541 skulls of the Sarmatian people and in 23 cases the features of internal frontal hyperostosis were detected. In 16 cases the features of this disease were found in male skulls. The researchers supposed that the reasons of Morgagni's syndrome wide spread among nomadic population could be adaptation consequences to camp life mode along with many systemic disturbances in the organism [5, p.212]. M.A. Balabanova researching demographic and anthropological peculiarities of the Sarmatians, firstly pointed that aged changes in the form of osteophytes on the joints and vertebrae of the of postcranial nomad skeletons bones of II-IV cC. A.D., described cases of intravital tooth loss and atrophy dentition, and also found traces of violent death on the bones of young men - extensive chopped wounds on the skeletons [2, p. 268]. E.V. Pererva with the help of paleopathological analysis conducted analysis of tooth system state of the late Sarmatians, anomalies extension rates on the bones of skeleton, inflammatory process symptoms, degenerative-dystrophic changes and traumatism character $[11,147]$. 
Dvornichenko, Smirnov, Fedorov-Davydov and others, analyzing the late sarmatians skeletons, fixed the great percent (more $70 \%$ ) of traumatic injuries of various origin: fractures, injuries, cut, chopped, shooting and punctured wounds. Also degenerative-dystrophic changes, according to which the high level of male skeletons physical exhaustion is registered, are fixed in great volume on the latesarmatians bones. High frequency of leg traumas, clavicle fractures, and also deprivation of lumbal and other sections of vertebral column sometimes with concrescence and separate blocs formation differs the late Sarmatians as horsemen from settled pedestrian population [2, 269].

Thus, historical sources allow educating of medical culture of the North Black sea region population - the unique place of centuries-long active interaction of ethnoses and culture. The concrete-historical methods, medical treatment devices, forms and content of medical knowledge, hygienic and phylactic experiences of such people, as the Scythians and the Sarmatians are reflected in them. On the analysis basis of written, archeologic, anthropological sources, one can draw a conclusion that medical culture of these people represents the complex of medical norms, values, skills, traditions, customs connected with preservation of health, diseases treatment.

\section{Лumepamypa}

1. Алексеев С.В., Инков А.А. Скифы: исчезнувшие владыки степей. М., 2015.

2. Балабанова М.А. Краниология сарматского населения, оставившего курганные группы Абганеровского могильника // Историко-археологические исследования в Нижнем Поволжье. Волгоград, 1997.

3. Белова Л.И., Гуляева Е.Ш., Чернышева И.В. Исторические свидетельства о медицинской культуре народов Нижнего Поволжья с раннего железного века до распада Золотой Орды. Известия Волгоградского государственного педагогического университета. 2016. № 3 (107).

4. Белова Л.И., Чернышева И.В., Черёмушникова И.К. Медицинская культура кочевых народов Нижнего Поволжья // Международный научноисследовательский журнал. 2015. № 10-4 (41).

5. Бужилова А.П., Соколова М.A., Перерва Е. В. Об эндокринных нарушениях у кочевых народов (на примере отдельных представителей сарматской культуры) // Opus: Междисциплинарные исследования в археологии. М., 2005. Вып. 4.

6. Галицкий A.B. Щедрый жар. Очерки о русской бане и ее близких и дальних родичах. М., 1980.

7. Гиппократ «О воздухе, водах, местностях» // Античные источники. Электронный ресурс. Режим доступа: http://www.ruistor.ru/istochniki_ant_011.html

8. Королькова Е. Ф. Великая богиня, божественный всадник и загадочные энареи: попытка интерпретации // Гунны, готы и сарматы между Волгой и Дунаем. СПб., 2009.

9. Лунин Б.В. Очерки истории Подонья-Приазовья. Книга І. Ростов-на-Дону, 1949. Электронный ресурс. Режим доступа: http://rostovregion.ru/books/item/f00/s00/z0000013/st009.shtml)

10. Нефёдкин А.К. Военное дело сарматов и аланов (поданным античных источников). СПб., 2011.

11. Перерва E.B. Палеопатология поздних сарматов из могильников Есауловского Аксая // OPUS: Междисциплинарные исследования в археологии. М., 2002. Вып. 1-2.

12. Плутарх Застольные беседы / Пер. М.Л. Гаспарова. Ленинград, 1990. 
13. Рохлин Д.Г. Болезни древних людей: (Кости людей различных эпох: нормальные и патологические изменения). М.; Л., 1960.

14. Финкельштейн М.А. Рентгенологические исследования палеопатологических материалов из могильников у сел Новоникольского и Верхнее Погромное // Очерки по истории древних племен Нижнего Поволжья. Л., 1975.

15. Хирургия в изобразительном искусстве / А.А. Воробьев, И.А. Петрова. Волгоград, 2005.

\section{References}

1. Alekseev S.V., Inkov A.A. The Scythians: the disappeared lords of heaths. M., 2015.

2. Balabanova M.A. Craniology of the Sarmatian population, left barrow groups of Abganerovskii burial ground // historical archaeological researchers in low Volga region. Volgograd, 1997. No. 2.

3. Belova L.I., Gulyaeva E.Sh., Chernysheva I.V. Historical testimonies about medical culture of low Volga region people from early Iron Age to the Golden Horde disintegration. The news of Volgograd state pedagogical university. 2016. No 3 (107).

4. Belova L.I., Chernysheva I.V., Cheremushnikova I.K. Medical culture of low Volga region nomadic people // International scientific and research journal. 2015.No10-4 (41).

5. Buzhilova A.P., Sokolova M.A., Pererva E. V. About endocrine disorders of nomadic people (at the example of the separate Sarmatian culture representatives) // Opus: Interdisciplinary researchers in archeology. M., 2005. No 4.

6. Galitsky A.V. Generous heat. Essays about Russian baths and its close and far relatives. M., 1980.

7. Hippocrates "About air, water, localities" // Ancient sources. [Electronic resource.] [Access mode] http://www.ruistor.ru/istochniki_ant_011.html

8. Korolkova E.F. The great divinity, celestial horseman and enigmatic enares: attempt of interpretation.// Huns, goths and the Sarmatians between Volga and Danube. St.P., 2009.

9. Lunin B.V. History essays. Book I. Rostov-on-Don, 1949. Electronic resource. Access mode:http://rostov-region.ru/books/item/f00/s00/z0000013/st009.shtml)

10. Nefedkin A. K. Military art of the Sarmatians and Alans (according to the data of antique sources). St.P., 2011.

11. Pererva E.V. Paleopathology of the late Sarmatians from burial grounds of Yesaul Aqsay // OPUS: Interdisciplinary researches in archeology. M., 2002. No. 1-2.

12. Plutarkh Table-talks / Trans. M.L.Gasparov. Leningrad, 1990.

13. Pokhlin D.G. The diseases of ancient people: (People' bones of various epochs: normal and pathologic changes). M.; L., 1960.

14. Finkelstein M.A. Roentgen examinations of paleopathological materials from burial grounds of Novonilskoye and Verkhnee Pogromnoe villages // Essays on the low Volga region ancient tribes history. L., 1975.

15. Surgery in visual art / A.A. Vorobyev, I.A. Petrova. Volgograd, 2005.

February, 14, 2017 